\title{
Profil Kasus Kekerasan Seksual terhadap Perempuan dan Anak yang Diperiksa di Rumah Sakit Bhayangkara Dumai (2009-2013)
}

\section{Profile of Sexual Abuse among Woman and Child in Bhayangkara Police Hospital Dumai (2009-2013)}

\author{
Mohammad Tegar Indrayana ${ }^{1}$ \\ ${ }^{1}$ Kelompok Jabatan Fungsional (KJF) Kedokteran Forensik dan Legal, Fakultas Kedokteran Universitas Riau
}

\begin{abstract}
ABSTRAK
Kekerasan seksual merupakan permasalahan hukum di masyarakat dan pelanggaran hak asasi manusia yang serius. Kekerasan seksual adalah salah satu dari kejahatan yang angka peningkatan kasus yang tinggi dan kasus kejahatan yang paling serius. Angka kekerasan seksual meningkat setiap tahunnya. Penelitian ini adalah penelitian cross sectional dengan metode total sampel. Hasil penelitian menunjukkan bahwa terdapat 120 kasus kekerasan seksual dari tahun 2009 sampai 2014. Secara umum, korban berjenis kelamin perempuan $(99,1 \%)$ dengan usia 0-18 tahun $(95,8 \%)$ dan merupakan seorang pelajar (59,17\%). Kasus paling sering adalah kasus kekerasan (95,83\%) dengan kekerasan tumpul (99,16\%), dimana sebagian besar korban memiliki robekan lama pada selaput dara $(68,33 \%)$. Kepolisian yang paling banyak meminta pembuatan Visum et repertum dari kekerasan seksual adalah kepolisian resor Kota Dumai $(76,67 \%)$.

Kata kunci: kekerasan seksual, Visum et Repertum, Dumai
\end{abstract}

\begin{abstract}
Sexual abuse is a serious public health and human right problem. Sexual abuse is one of the most rapidly increasing and the most serious violence crimes. The number of sexual abuse cases is increasing annually. This study is a cross sectional with total sampling method. The result showed are 120 cases of sexual violences from 2009 until 2014. Generally, the victims were women $(99,1 \%)$ aged $0-18$ years $(95,8 \%)$ and the status is students $(59,17 \%)$. The most common case is an abuse cases $(95,83 \%)$ with blunt violence (99,16\%), which most of the victims had an old rip on the hymen (68,33\%). The district that request the VeR of sexual crime the most is Dumai City police (76,67\%).
\end{abstract}

Keywords: Sexual abuse, visum et repertum, Dumai

Korespondensi : Mohammad Tegar Indrayana, email: tegar.forensik@gmail.com

Artikel info: Online published first 14 September 2017.

DOI: https://doi.org/10.26891/jkm.v1i1.2017.9-13

Copyright @ 2017 Authors. This is an open access article distributed under the terms of the Creative Commons Attribution-NonCommercial 4.0 International License (http://creativecommons.org/licenses/by-nc/4.0/), which permits unrestricted non-commercial use, distribution, and reproduction in any medium, provided the original author and source are properly cited 
Kekerasan seksual masih menjadi permasalahan serius di masyarakat kita dewasa ini. Hal ini tercermin dari banyaknya pemberitaan di media massa yang mengabarkan berbagai macam tindak kekerasan seksual baik itu pemerkosaan maupun pencabulan. Sampurna (2005) menyatakan bahwa kekerasan seksual mempunyai arti terhadap setiap penyerangan yang bersifat seksual terhadap perempuan, baik telah terjadi persetubuhan ataupun tidak, dan tanpa memperdulikan hubungan antara pelaku dengan korban. ${ }^{1}$

Secara statistik, jumlah kasus pemerkosaan di dunia cukup tinggi. Hal ini dapat dilihat dari data di Amerika Serikat yang melaporkan bahwa 75.000 kasus pemerkosaan terjadi tiap tahun, dan $90 \%$ diantaranya dialami oleh perempuan yang memiliki kesamaan ras dengan pelakunya dan $76 \%$ dikenal oleh korban dan seringnya adalah anggota keluarga korban. ${ }^{2-4}$

Komisi Nasional Perempuan (Komnas Perempuan) melaporkan bahwa terdapat 15 jenis kasus kekerasan seksual yang terjadi di Indonesia sejak tahun 1998 hingga 2013. ${ }^{5}$ Penelitian yang dilakukan oleh Butar-butar (2012) menyimpulkan bahwa terdapat 120 kasus kekerasan seksual yang diperiksa di Rumah Sakit Bhayangkara Pekanbaru selama tahun $2011 .^{6}$

\section{METODE}

Penelitian ini dilakukan dengan pendekatan potong lintang (cross sectional). Penelitian ini dilakukan dengan mengambil data Visum et Repertum di Rumah Sakit Bhayangkara Dumai yang dilaksanakan pada bulan Agustus 2016 dan dilakukan di Rumah Sakit Bhayangkara Dumai. Populasi dalam penelitian ini adalah seluruh VeR kekerasan seksual yang dibuat di Rumah Sakit Bhayangkara Dumaiperiode 1 Januari 2009 hingga 31 Desember 2014. Sampel dalam penelitian ini adalah seluruh VeR kejahatan seksual di Rumah Sakit Bhayangkara Dumai periode 1 Januari 2009 hingga 31 Desember 2014yang memenuhi kriteria, yaitu lengkapnya data profil korban. Pengambilan sampel dilakukan dengan menggunakan metode total sampling.

Tujuan dari penelitian ini adalah untuk mengetahui profil kasus kekerasan seksual terhadap perempuan dan anak di Rumah Sakit Bhayangkara Dumai periode 1 Januari 2009 hingga 31 Desember 2013.

Pengolahan data dalam penelitian ini dilakukan dengan menggunakan langkah editing, koding dan entry data. Analisis data menggunakan analisis univariat untuk melihat profil kasus kekerasan seksual di Rumah Sakit Bhayangkara Dumai periode 1 Januari 2009 hingga 31 Desember 2014. Hasil penelitian disajikan secara deskriptif dalam bentuk tabel distribusi frekuensi.

\section{HASIL}

Berdasarkan penelitian, jumlah VeR kejahatan seksual periode 1 Januari 2009-31 Desember 2013 diperoleh sebanyak 120 VeR seperti yang digambarkan pada Gambar 1.

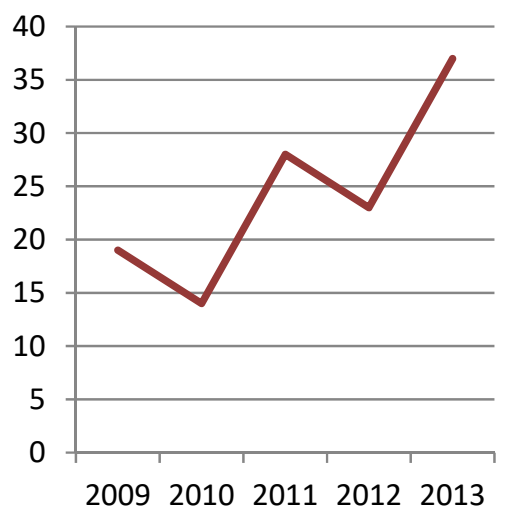

Gambar 1. Jumlah VeR korban hidup kejahatan seksual periode 1 Januari 2009-31 Desember 2013.

Tabel 1 menunjukkan bahwa jumlah korban hidup kasus kekerasan seksual yang tertinggi berada pada kelompok usia 0-18 tahun yaitu sebanyak 115 (95,83\%) korban sedangkan yang terendah berada pada kelompok usia $>45$ tahun yaitu sebanyak 0 korban.

Tabel 1. Gambaran korban hidup kasus kejahatan seksual yang dimintakan VeR periode 1 Januari 2009-31 Desember 2013

\begin{tabular}{lccc}
\hline Variabel & Jenis Kelamin & & Total \\
\hline & Laki-laki & Perempuan & \\
\hline$\bullet$ 0-18 & $1(0,83)$ & $114(95,00)$ & $\begin{array}{c}115 \\
(95,83)\end{array}$ \\
\hline$\bullet 19-24$ & $0(0)$ & $4(3,33)$ & $4(3,33)$ \\
\hline$\bullet 25-44$ & $0(0)$ & $1(0,83)$ & $1(0,83)$ \\
\hline$\bullet 45-64$ & $0(0)$ & $0(0)$ & $0(0)$ \\
\hline$\bullet>65$ & $0(0)$ & $0(0)$ & $0(0)$ \\
\hline Total & $1(0,83)$ & $119(99,2)$ & $120(100)$ \\
\hline
\end{tabular}

Dari 120 korban hidup kasus kekerasan seksual yang dimintakan VeR, 119 korban diantaranya berjenis kelamin perempuan dengan kelompok usia tertinggi berada pada usia 0-18 tahun sebanyak 114 (95\%) korban dan terendah berada pada usia $>45$ tahun sebanyak 0 korban. Sedangkan korban hidup kasus kejahatan seksual berjenis kelamin laki-laki hanya terdapat $1(0,83 \%)$ korban pada kelompok usia 0-18 tahun.

Tabel 2. Gambaran pekerjaan korban kekerasan seksual yang dimintakan VeR kejahatan seksual periode 1 Januari 2009-31 Desember 2013

\begin{tabular}{ccc}
\hline Variabel & Frekuensi $(\mathbf{n = 1 2 0})$ & Persentase (\%) \\
\hline Tidak bekerja & 41 & 34.17 \\
Pelajar & 71 & 59.17 \\
Mahasiswa & 0 & 0 \\
Ibu Rumah & 1 & 0.83 \\
Tangga & 0 & 0 \\
Pegawai & 5 & 4.17 \\
Wiraswasta & 2 & 1.67 \\
Tidak ada data & 120 & 100 \\
Total & &
\end{tabular}


Gambaran pekerjaan korban hidup kasus kekerasan seksual yang tertinggi adalah pelajar sebanyak $71(59,17 \%)$ korban sedangkan yang terendah adalah wiraswasta sebanyak 5 (4,17\%) korban yang dapat dilihat pada tabel 2 . Gambaran jenis kasus korban hidup kasus kekerasan seksual yang tertinggi yaitu kasus pencabulan sebanyak 115 (95,83\%) korban sedangkan yang terendah adalah perzinahan dan pelecehan seksual masing-masing sebanyak 1 (0,83\%) korban, gambaran jenis kasus dapat dilihat di tabel 3.

Tabel 3. Gambaran jenis kasus pada korban kekerasan seksual yang dimintakan VeR kejahatan seksual periode 1 Januari 2009-31 Desember 2013

\begin{tabular}{lcc}
\hline \multicolumn{1}{c}{ Variabel } & $\begin{array}{c}\text { Frekuensi } \\
(\mathbf{n = 1 2 0 )}\end{array}$ & $\begin{array}{c}\text { Persentase } \\
(\mathbf{\%})\end{array}$ \\
\hline Perkosaan & 3 & 2.50 \\
Pencabulan & 115 & 95.83 \\
Perzinahan & 1 & 0.83 \\
Pelecehan seksual & 1 & 0.83 \\
Total & 120 & 100.00 \\
\hline
\end{tabular}

Jenis kekerasan yang paling banyak ditemukan pada VeR kejahatan seksual di RS Bhayangkara Dumai periode 1 Januari 2009-31 Desember 2013 adalah kekerasan tumpul yang berjumlah 119 (99,16\%) kasus, sedangkan 1 (0,83\%) korban lainnya mendapatkan jenis kekerasan tajam dan tumpul. Jenis kekerasan yang dialami korban hidup kasus kekerasan seksual yang dimintakan VeR kejahatan seksual di RS Bhayangkara Dumai periode 1 Januari 2009-31 Desember 2013 dapat dilihat pada gambar 2.

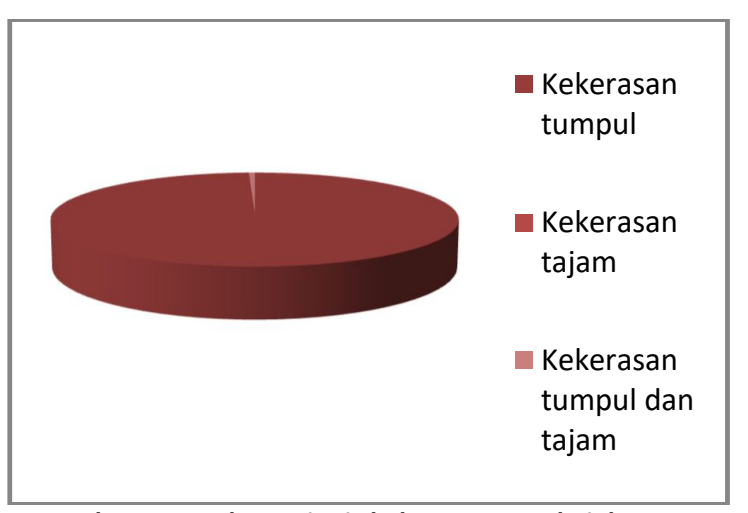

Gambar 2. Gambaran jenis kekerasan VeR kejahatan seksual periode 1 Januari 2009-31 Desember 2013

Gambaran jenis luka korban hidup kekerasan seksual pada VeR kejahatan seksual di RS Bhayangkara Dumai pada periode 1 Januari 2009-31 Desember 2013 yaitu ditemukan 1 contusio pada kepala dan punggung.

Gambaran kondisi selaput dara korban hidup kasus kekerasan seksual yang tertinggi adalah terdapat robekan lama pada sebanyak 82(68,33\%) korban. Sedangkan yang terendah adalah korban dengan kondisi selaput dara yang utuh dan tidak dapat ditentukan masing-masing 3(3,33\%) korban. Hasil penelitian ini dapat dilihat pada tabel 4.
Tabel 4. Gambaran kondisi selaput dara pada korban kekerasan seksual yang dimintakan VeR kejahatan seksual periode 1 Januari 2009-31 Desember 2013

\begin{tabular}{lcc}
\hline \multicolumn{1}{c}{ Variabel } & $\begin{array}{c}\text { Frekuensi } \\
\text { (n=120) }\end{array}$ & Persentase (\%) \\
\hline Utuh & 3 & 2.50 \\
Robekan Lama & 82 & 68.33 \\
Robekan Baru & 24 & 20.00 \\
Robekan Lama Dan & & \\
Baru & 4 & 3.33 \\
Tidak Dapat Ditentukan & 3 & 2.50 \\
Tidak Ada Data & 4 & 3.33 \\
Total & 120 & 2.50 \\
\hline
\end{tabular}

Gambaran kondisi anus korban hidup kekerasan seksual pada VeR kejahatan seksual di RS Bhayangkara Dumai pada periode 1 Januari 2009-31 Desember 2013 didapatkan kondisi anus dengan luka lecet pada 1 korban dan kondisi normal pada 2 korban. Sedangkan 117 korban lainnya tidak dilakukan pemeriksaan anus.

Berdasarkan penelitian ini terlihat Polsek pengirim kasus korban hidup kekerasan seksual tertinggi dari Polisi Resor Dumai Kota sebanyak $92(76,67 \%)$ korban, sedangkan terendah dari Polsek Dumai Selatan sebanyak $1(0,83 \%)$ korban. Gambaran ini dapat dilihat pada tabel 5.

Tabel 5. Gambaran Polsek pengirim pada korban kekerasan seksual yang dimintakan VeR kejahatan seksual periode 1 Januari 2009-31 Desember 2013

\begin{tabular}{lcc}
\hline \multicolumn{1}{c}{ Variabel } & $\begin{array}{c}\text { Frekuensi } \\
(\mathbf{n = 1 2 0})\end{array}$ & Persentase (\%) \\
\hline Dumai Barat & 10 & 8.33 \\
Dumai Timur & 6 & 5.00 \\
Bukit Kapur & 5 & 4.17 \\
Medang & & \\
Kampai & 4 & 3.33 \\
Sungai & & \\
Sembilan & 2 & 1.67 \\
Dumai Kota & 92 & 76.67 \\
Dumai & & \\
Selatan & 1 & 0.83 \\
Total & 120 & 100 \\
\hline
\end{tabular}

\section{DISKUSI}

Hasil observasi kasus kekerasan seksual di Rumah Sakit Bhayangkara Dumai Polda Riau terlihat bahwa angka kejadiannya memiliki kecenderungan mengalami peningkatan dari tahun ke tahun. Hal ini tidak hanya terjadi di Kota Dumai namun juga di beberapa kota di Indonesia. Dari laporan Universitas Gajah Mada mengungkapkan bahwa sebanyak enam ibu kota provinsi di Indonesia selama tahun 1999 ditemukan sebanyak 27 kasus seksual terhadap anak. Rangkuman data Kekerasan terhadap Perempuan di Indonesia tahun 2002 yang dihimpun oleh Komnas Perempuan menunjukkan terdapat 330 kasus kekerasan seksual, 42 kasus pelecehan seksual dan 171 kasus perkosaan anak. $^{7}$

Berdasarkan data yang diperoleh dari Pusat Pelayanan Terpadu Pemberdayaan Perempuan dan Anak (P2TP2A) Kota Dumai sepanjang tahun 2014 terdapat 32 kasus kekerasan seksual. Hasil data yang diperoleh dari Rumah Sakit Bhayangkara Dumai serta data dari P2TP2A diatas, 
terlihat bahwa kekerasan seksual merupakan suatu kejahatan yang bersifat universal dan dapat terjadi dimana saja tanpa memandang usia maupun jenis kelamin. Meskipun pada penelitian ini didapatkan sebagian besar terjadi pada kelompok usia dibawah 18 tahun dan berjenis kelamin perempuan.

Hasil penelitian diatas sesuai dengan penelitian di Cape Town, Afrika Selatan tahun 2008 dimana dari 820 korban yang diperiksa, 76,5\% berusia 10-19 tahun dan juga sesuai dengan penelitian di Turki pada tahun 2013, dimana ditemukan sebanyak 268 dari 324 korban kejahatan seksual berjenis kelamin perempuan. Hasil yang berbeda didapatkan dari hasil survei kekerasan terhadap anak Indonesia tahun 2013, dimana pada survei kekerasan terhadap anak Indonesia tahun 2013 usia yang paling banyak pada kekerasan terhadap anak adalah pada usia 18-24 tahun dan jenis kelamin yang paling banyak adalah laki-laki. ${ }^{8-10}$

Sebanyak 71 orang $(59,17 \%)$ korban kejahatan seksual yang diperiksa di Rumah Sakit Bhayangkara Dumai berstatus sebagai pelajar, sejalan dengan prevalensi usia tebanyak korban kejahatan seksual yang berusia 0-18 tahun. Hal ini sesuai dengan penelitian di Denmark yang menyebutkan sebanyak 187 dari 423 korban kejahatan seksual berstatus sebagai pelajar. ${ }^{11}$

Jenis kejahatan seksual yang sesuai dengan penelitian di atas, dimana sebanyak 115 orang (95,83\%) korban kejahatan seksual adalah kasus pencabulan. Hal ini sesuai dengan hasil penelitian Riandsya A di Rumah Sakit Bhaayangkara Pekanbaru periode tahun 2010-2014, dimana kasus pencabulan merupakan kasus terbanyak dengan jumlah 346 kasus $(55,4 \%) .{ }^{12}$

Berdasarkan jenis kekerasan, jenis luka dan lokasi luka paling banyak yang ditemukan pada kasus kejahatan seksual di Rumah Sakit Bhayangkara Dumai secara berturut-turut adalah kekerasan tumpul, memar dan kepala serta punggung. Hal ini sesuai dengan penelitian yang dilakukan oleh Riandsya A di Rumah Sakit Bhaayangkara Pekanbaru periode tahun 2010-2014, dimana kekerasan tumpul merupakan kasus terbanyak pada korban kejahatan seksual. Jenis luka memar yang ditemukan pada penelitian ini sesuai dengan penelitian di Nepal tahun 2009, dimana memar merupakan jenis luka terbanyak yaitu $28,7 \%$ dari 1372 jenis luka, dengan regio terbanyak pada kepala dan leher sebagai lokasi luka yang terbanyak yang ditemukan sebesar $57,06 \% .12,13$

Kondisi selaput dara yang banyak ditemukan adalah robekan lama $(68,33 \%)$, dimana hal ini sesuai dengan penelitian yang dilakukan di Rumah Sakit Bhayangkara Pekanbaru pada periode tahun 2010-2014 ditemukan robekan lama (48\%) yang merupakan kondisi selaput dara terbanyak pada kejahatan seksual. ${ }^{12}$

Pada penelitian ini, pemeriksaan anus hanya dilakukan pada 3 kasus dari 120 kasus yang diperiksa di Rumah Sakit Bhayangkara Dumai. Hal ini secara standar pemeriksaan fisik kekerasan seksual pada anak tidak memenuhi standar. Karena seharusnya setiap kasus kekerasan seksual pada anak wajib dilakukan pemeriksaan pada anus sebagaimana yang telah ditetapkan pada Buku Pedoman Deteksi Dini, Pelaporan dan Rujukan Kasus Kekerasan dan Penelantaran Anak. ${ }^{14}$

Kota Dumai merupakah salah satu Kabupaten/kota yang ada di Provinsi Riau. Berdasarkan data dari Badan Pusat Statistik kota Dumai tahun 2016 jumlah penduduk dan tindak pidana yang ada di Kota Dumai, terbanyak berturutturut ditemukan di Dumai Timur yaitu 61.685 jiwa dengan
316 kasus pidana. Hal ini sesuai dengan penelitian Riandsya A yang menyatakan bahwa tingginya jumlah penduduk memengaruhi tingginya angka kriminalitas. Namun hasil tersebut bertolak belakang dengan penelitian ini, dimana Polsek pengirim terbanyak adalah Dumai Kota $(76,67 \%)$ yang mempunyai jumlah penduduk lebih sedikit dibandingkan dengan Dumai Timur dan tidak ditemukannya angka tindak pidana pada tahun 20132015. ${ }^{12,15}$

\section{Ucapan Terima Kasih}

Penulis mengucapkan terima kasih kepada Rumah Sakit Bhayangkara Dumai atas izin yang diberikan. Achsanul Kubri dan Puji Yunisyah Rahayu (Dokter Muda Kepaniteraan Klinik Forensik dan IImu Medikolegal), petugas tata usaha dan rekam medis untuk kesediaan waktunya mengumpulkan data visum et repertum.

\section{DAFTAR PUSTAKA}

1. Sampurna B, Samsu Z, Siswaja TD. Kekerasan Terhadap Perempuan. Dalam: Peranan IImu Forensik dalam Penegakan Hukum Sebuah Pengantar. Jakarta: Pustaka Dwipa, 2005. Hal 122

2. Brown KP, Sommers MS. Injury and Forensic Examination of The Victim. In: Practical Aspect of Rape Investigation, A Multidisciplinary Approach. Fourth Edition. Hazelwood RR, Burgess AW, editors. Boca Raton: CRC Press, 2009.

3. MacDonald R. Time to Talk About Rape. BMJ 2000: 321; 1034-35.

4. Wilken J, Welch J. Management of People Who Have Been Rape. BMJ 2003:326;458-59.

5. 15 jenis kekerasan seksual [internet]. 2013 [dikutip pada 23 Februari 2015]. Tersedia: http://www.komnasperempuan.or.id/wpcontent/uploads/2013/12/15-Jenis-KekerasanSeksual_2013.pdf

6. Butar Butar Y. Profil kasus kejahatan seksual yang diperiksa di Rumah Sakit Bhayangkara Tingkat IV Pekanbaru periode 1 Januari 2011- 31 Desember 2011 [Skripsi]. Pekanbaru: Fakultas Kedokteran Universitas Riau; 2012.

7. Pedoman Penatalaksanaan Pelayanan Terpadu Korban Kekerasan Terhadap Perempuan dan Kekerasan Terhadap Anak di Rumah Sakit. Jakarta: Direktorat Pelayanan Medik Departemen Kesehatan RI, 2003.

8. Kurniasari A, Wismayanti $\mathrm{Y}$, Irmayani, Husmiati, Widodo N, Susyanto B. Ringkasan hasil survey kekerasan terhadap anak Indonesia tahun 2013. Kerjasama Kementrian Sosial, Kementerian Pemberdayaan Perempuan dan Perlindungan Anak, Badan Perencanaan Pembangunan Nasional, Bada Pusat Statistik, UNICEF. Jakarta;2013. Hal 3

9. Karafil R, Keten A, Zeren C, Arslan MM, Eren A. Evaluation of sexual assaults in Turkey. Journal of Forensic and Legal Medicine. 2013 Mar; 20:404-7

10. Golan A, Dishi-Galitzky M, Barda J, Lurie A. The care of sexual assaults victims: the first regional center in 
Isreael-10 years experience. IMAJ. 2012 Nov 29; 14:658-61

11. Ingemann-Hansen $O$, Sabroe $S$, Brink $O$, Knudsen $M$, Charles AV. Characteristic of victims and assaults of sexual violence - improving inquiries and prevention. Journal of Forensic and Legal Medicine. 2008 Oct; 16: $182-8$

12. Riandsya A. Profil kasus kejahatan seksual yang diperiksa di rumah sakit bhayangkara pekanbaru periode 2010-2014 [Skripsi]. Pekanbaru: Fakultas Kedokteran Universitas Riau;2015.

13. Subba SH, Binu VS, Menezes RG, Kumar V, Rana MS. Physical about assault related injuries in Western Nepal - a hospital based retrospective study. Journal of Forensic and Legal Medicine. 2010 Mar; 17: 203-8.

14. Depkes RI. IDI. UNICEF (2005). Buku pedoman deteksi dini, pelaporan dan rujukan kasus kekerasan dan penelantaran anak bagi tenaga kesehatan. Jakarta: Indonesia Printer.

15. Badan Pusat Statistik Kota Dumai, 2016. Kota dumai dalam angka 2016. Dumai: Badan Pusat Statistik 